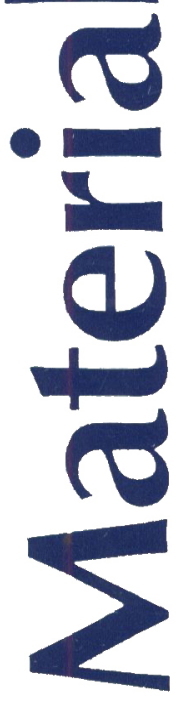

0 ob (4)

\title{
CUMULATIVE INDEX
}

1980-1989 Volumes xix-xxviif

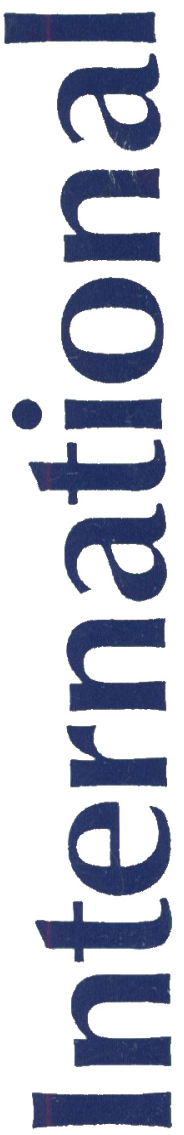




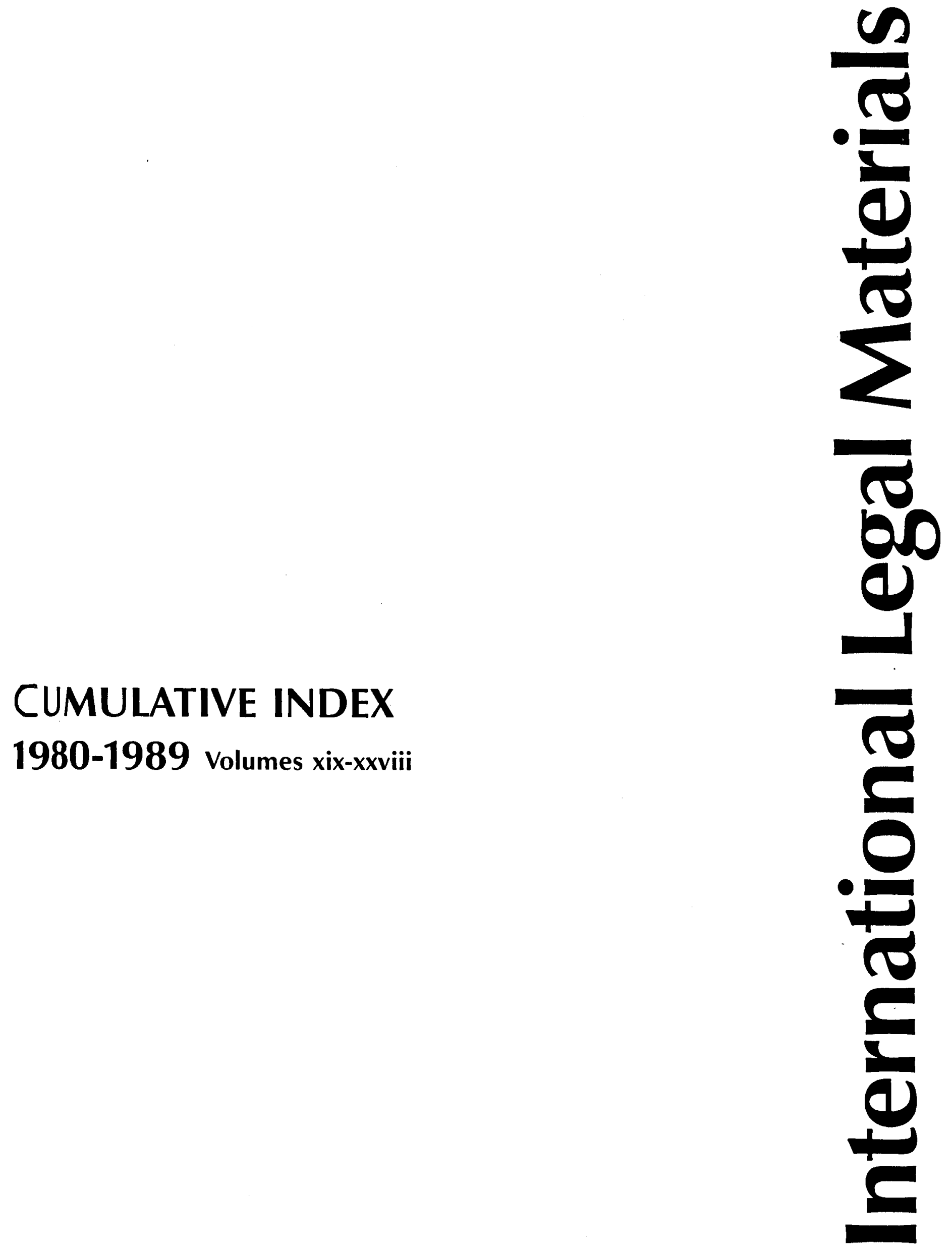




\section{Subscription Information}

International Legal Materials (ISSN 0020-7829) is published bimonthly (January, March, May, July, September, November) by The American Society of International Law, 2223 Massachusetts Avenue, N.W., Washington, D.C. 20008-2864. The annual subscription rate for nonmembers of the Society is $\$ 125$; members of the Society may subscribe for $\$ 65$ a year. $\$ 6.50$ should be added for all foreign subscriptions to cover postage costs. The equivalent UNESCO coupons are acceptable for subscriptions to International Legal Materials.

\section{Back Issues, Cumulative Indexes and Microfiche}

All back issues are available. Volumes 1-18 (1962-1979) are available from William S. Hein \& Company, 1285 Main Street, Buffalo, New York 14209. Volumes 19-28 (1980-1989) are available directly from International Legal Materials.

Single copies are $\$ 25$ each plus $\$ 2.50$ for postage and handling. Complete volumes (six issues) are $\$ 150$ per volume plus $\$ 6.50$ for postage and handling. Volume 1 consists of only two issues; the cost for this volume is $\$ 50$ plus $\$ 2.50$ for postage and handling.

An annual table of contents and an annual index are carried in the November issue of each volume. Cumulative Indexes are available from International Legal Materials for the following periods: 1962-1969, 19701979, and 1980-1989. The 1962-1969 Index costs $\$ 31.50$ for Society members and $\$ 43$ for nonmembers. The 1970-1979 Index costs $\$ 43.50$ for members and $\$ 51$ for nonmembers. The 1980-1989 Index costs $\$ 49.50$ for members and $\$ 58$ for nonmembers. An additional payment of $\$ 2.50$ to cover postage and handling must accompany all index orders.

Complete sets and odd volumes of International Legal Materials are available on microfiche from William S. Hein \& Company, 1285 Main Street, Buffalo, N.Y. 14209. International Legal Materials is indexed by $A B C$ POL SCl, Current Law Index, Marine Affairs Bibliography, and Public Affairs Information Service.

\section{Change of Address and Correspondence}

Please inform the Circulation Department of a change of address in writing at least 60 days prior to moving in order to assure uninterrupted receipt of ILM. Your post office will not automatically forward your subscription, and failure to inform us of an address change may result in billing for additional postage.
All correspondence regarding subscriptions, back issues, and cumulative indexes should be addressed to the Circulation Department, International Legal Materials, 2223 Massachusetts Avenue, N.W., Washington, D.C. 20008-2864 (telephone 202-265-4313)

\section{Advertising}

Inquiries about rates and specifications should be directed to the Advertising Department at the above address.

\section{Editorial Policy}

International Legal Materials is a collection of current documents designed to provide up-to-date information to scholars, practicing lawyers, legal advisers to government agencies and corporations, national and international officials, and others concerned with the legal aspects of public and private international relations. These documents primarily consist of current materials not readily available in most libraries.

The term international law is interpreted broadly for the purposes of this publication. Some of the materials may be of a kind normally classified under other rubrics, such as foreign law, comparative law, conflict of laws, constitutional law, international organization, and the like. The main criterion in selecting materials is that the document be of substantial interest to a large number of legal scholars, practicing lawyers and officials dealing with public and private international matters. It is recognized that these interests may vary considerably among users of the publication in the United States and elsewhere.

International Legal Materials reproduces by photo-offset the official documents whenever possible. In some instances, the documents are reproduced from unofficial typescript when texts are unavailable or when a translation is given. A short "I.L.M. Background/Content Summary" precedes each document to assist in reviewing the materials. On occasion, "Introductory Notes" also accompany documents. The authors of such notes are identified.

Readers are invited to draw the Editor's attention to documents meriting reproduction in International Legal Materials.

Second class postage paid at Washington, D.C. POSTMASTER: Send address changes and returns to International Legal Materials, 2223 Massachusetts Avenue, N.W., Washington, D.C. 20008-2864. Return postage guaranteed.

Authorization to photocopy items for internal or personal use, or the internal or personal use of specific clients, is granted by the American Society of International Law for users registered with the Copyright Clearance Center (CCC) Transactional Reporting Service, provided that the base fee of $\$ 10.00$ per copy, plus $25 \$$ per page is paid directly to CCC, 27 Congress St., Salem, MA 01970. For those organizations that have been granted a photocopy license by CCC, a separate system of payment has been arranged. The fee code for users of the Transactional Reporting Service is: 0020-7829/90\$10.00+.25. 


\author{
Editor \\ Marilou M. Righini \\ Editorial Advisory Committee \\ John Lawrence Hargrove, Chairman \\ Domingo E. Acevedo \\ Marie-Louise $\mathrm{H}$. Bernal \\ Marjorie Ann Browne \\ Eli Whitney Debevoise II \\ Ceorges R. Delaume \\ Gary N. Horlick \\ Cecil Hunt \\ Bruno A. Ristau \\ Jonathan B. Schwartz \\ Miranda S. Wecker \\ Edith Brown Weiss \\ Carol A. Williams \\ Seymour J. Rubin, Member Emeritus \\ Assistant Editor for the \\ International Law Information System Project \\ Samuel W. Bettwy

\section{Individuals Assisting as Corresponding Editors}

Evelina Teubal de Alhadeff (Argentina)

David J. Attard (Malta)

Jean-François Bellis (European Communities)

John A. Boyd (Southeast Asia)

Thomas Buergenthal (Inter-American Court of Human Rights)

William E. Butler (USSR)

Antônio Augusto Cançado Trindade (Brazil)

James H. Carter (New York)

Sudhir K. Chopra (India)

Carl Q. Christol (Outer Space and

Telecommunications)

John P. Cogan, Jr. (Houston)

John Dugard (Southern Africa)

Richard W. Edwards (International Monetary System)

Carlos A. Esplugues (Spain)

Eduardo Ferrero (Peru)

Richard I. Fine (Los Angeles)

Eiichi Fukatsu (Japan)

Emmanuel Gaillard (France)

Heribert Golsong (International Investment)

Dencho Georgiev (Bulgaria)

Scott A. Hajost (Environment)

Krateros M. loannou (Greece)

Larry D. Johnson (United Nations)

Kanwar Jeet Singh Kapoor (Asian-African Legal

Consultative Committee)

Kenneth Klein (International Taxation)
Peter Lambert (Austria)

Arnold H. Leibowitz (Immigration)

Frankie F. L. Leung (Hong Kong)

Michael O'Boyle (European Commission and Court of Human Rights)

Alexandre Papandreou (Council of Europe)

John R. Pate (Andean Group)

Charles H. Poncet (Switzerland)

Amelia Porges (GATT)

Maurizio Ragazzi (Italy)

Douglas Reichert (Iran-United States Claims Tribunal)

Bernardo Rodríguez Ossa (Colombia)

Philip Sacks (Australia)

Ewa Salkiewicz (Poland)

Andrew A. Sanfilippo (Canada)

Richard F. Scott (International Energy Agency)

Henri Smets (OECD)

Andrew B. Spiegel (Chicago)

Daniel D. Stein (China)

Jiri Toman (Law of War)

Anne M. Trebilcock (International Labour

Organisation)

Leonard H. W. van Sandick (The Netherlands)

Rebecca M. M. Wallace (United Kingdom)

Gerhard Wegen (Federal Republic of Germany)

Isidoro Zanotti (Organization of American States)

Nassib G. Ziadé (Middle East)

\section{Advertising and Promotion}

Rosemarie Rauzino-Heller
Editorial Assistants

Mark A. Adams

Rachel de la Vega

Alice Mui
Subscriptions

Martha J. McIntosh 


\section{EDITORIAL NOTE}

This 1980-1989 Index for International Legal Materials is a reference tool that makes the raw materials of ILM during the past decade alive and accessible, with additional information about the documents provided in the Tables at the front.

We have included entry into force dates for treaties and agreements or, if they had not yet entered into force as of December 31, 1989, we have indicated that so you may pursue your own investigation of entry into force. The Index contains some 100 general subject headings as well as geographic areas, countries, conferences, and international organizations. Please take a moment and review the instructions on page iii on "How to Use the Index".

International Legal Materials is indebted to Samuel W. Bettwy for indexing the 1980s volumes of ILM containing over 15,500 pages of documentary materials. The final product is the work and effort of a number of persons associated with ILM. Marie-Louise H. Bernal, Americo Beviglia Zampetti, Jason M. Jacobs, Therese D. Raphael, Katherine E. Snow and Tim S. Steenstrup assisted in obtaining the information for the Tables at the front; and special thanks goes to Rachel de la Vega for assembling the materials and overseeing the final stages of production. We trust our efforts have resulted in a useful index.

\section{TABLE OF CONTENTS}

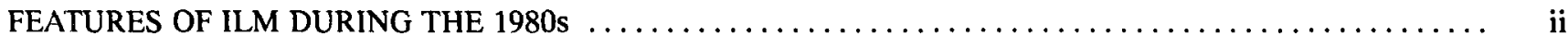

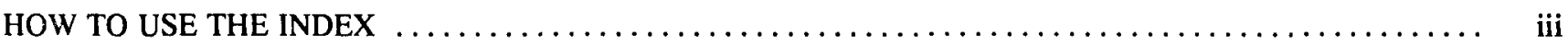

NEGOTIATING CONFERENCES REPORTED $\ldots \ldots \ldots \ldots \ldots \ldots \ldots \ldots \ldots \ldots \ldots \ldots \ldots \ldots \ldots \ldots \ldots \ldots \ldots$

TABLE OF TREATIES REPORTED

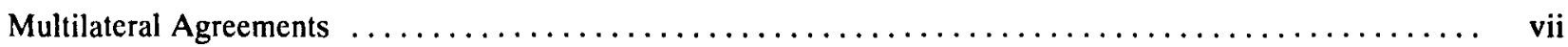

Bilateral Treaties to which the United States is a Party $\ldots \ldots \ldots \ldots \ldots \ldots \ldots \ldots \ldots \ldots \ldots \ldots \ldots \ldots \ldots \ldots \ldots$ xiv

Bilateral Treaties to which the United States is Not a Party $\ldots \ldots \ldots \ldots \ldots \ldots \ldots \ldots \ldots \ldots \ldots \ldots \ldots \ldots \ldots \ldots$

TABLE OF CASES REPORTED

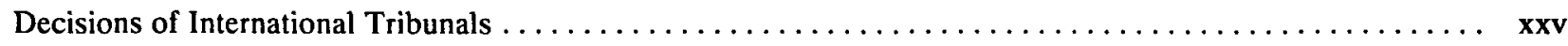

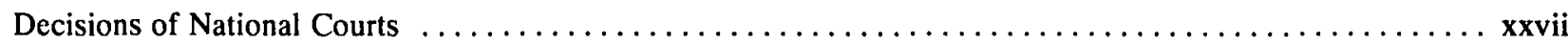

LIST OF GENERAL SUBJECT HEADINGS (Other than Conferences, Countries,

Geographic Areas, and International Organizations) $\ldots \ldots \ldots \ldots \ldots \ldots \ldots \ldots \ldots \ldots \ldots \ldots \ldots \ldots \ldots \ldots \ldots \ldots \ldots \ldots$

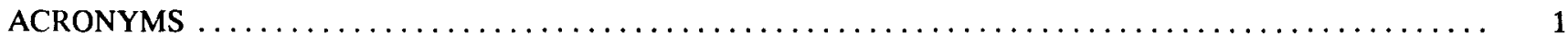

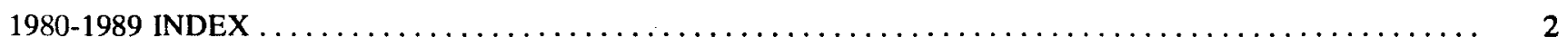

